\title{
FORMING THE DEVELOPMENT STRATEGY OF MODERN HEI
}

\author{
Kostiantyn Hromovenko', Yana Tytska² \\ International Humanitarian University, Ukraine
}

\begin{abstract}
The article analyses modern trends in supporting the development of financing of higher education in the European Union, namely: the evolution of financing strategies for higher education in 2010-2016, the change in the volume of financing of various systems for this period, and the criteria for the allocation of public funds in higher educational institutions. It is shown that countries, members of the EU, use different strategies for financing higher education but do not have a universal mechanism. Based on the analysis of European scholars' research, various mechanisms for financing higher education are presented, their tendencies are determined. Models of adaptive transition of HEls to modern conditions of functioning, using accessible tools and methods were considered. The proposed three scenarios for funding universities show that the strategy for financing HEls in the current dynamic development conditions should shift from a traditional model of public financing (supply-side) through the transformation to financing on the basis of socio-economic mechanisms (demand-side) using different tools. The EU countries use different financing strategies for HEls and do not have a universal mechanism. The amount of funding for higher education institutions depends both on quantitative (number of students) and qualitative (number of credits, diplomas) indicators. There is a tendency to allocate public funds to HEls on the basis of learning outcomes, as well as the tendency of combining different financing instruments in the context of a particular country, including the emergence of demand-side socio-economic financing mechanisms. Socio-economic financing on the basis of demand has several potential advantages. Firstly, students and firms, "consumers" of educational services, are key figures. These mechanisms can stimulate universities to be more efficient economically, and students - to improve academic results and increase internal efficiency. Secondly, the demand scenario mechanisms can be used regardless of the source of financing. They can be applied equally for the allocation of public resources and private financing of employers or students and their families. The main disadvantage of the mechanisms for financing HEls is that they are not interested in using funding for social and public programs and research with low economic efficiency. To apply one of the scenarios in a particular country, it is important to take into account not only national characteristics but also international trends. Competitiveness of international students, the emergence of the territory of a multinational educational platform and international ratings - all this play a significant role in the formation of strategic decisions for the HEls' development. An effective process of resource management of HEI should be based on strategic and financial benchmarks that provide for the development and implementation of a number of activities for the current activities of HEls aimed at achieving the normal sustainability of the funding system and enhancing the university's competitive advantages. For this purpose, a scheme for shaping the development strategy of the HEl was developed and a methodology was proposed for calculating the scientific and educational effectiveness of the university's activity, which includes three fundamental categories: the quality of the university's growth; the demand for scientific activity; scale, sustainability of scientific activity.
\end{abstract}

Key words: higher education, experience of EU countries, HEl financing strategies, financing conditions, financing mechanisms, HEl development scenarios, financing instruments, strategy scheme, HEl efficiency rating.

JEL Classification: 120, 121, 123, B25

\section{Introduction}

The qualitative system of higher education, being an indicator of the country's development, becomes the leading sphere of the social and economic policy of any state, reflecting the level of the state and development of society. The growing role of higher education is manifested in the solution of socio-economic, scientific and technological, socio-cultural, and spiritual and moral

\footnotetext{
Corresponding author:

${ }^{1}$ Department of International Law and Comparative Law, International Humanitarian University.

E-mail: gromovenkovikkos@gmail.com

${ }^{2}$ Department of Theory and History of State and Law, International Humanitarian University.

E-mail: yana1maslova@gmail.com
} 
problems and consists in preserving national traditions, and in the progressive impact on the development of the state's potential of the country.

The economic nature of higher education is understood as an investment in human capital. Education is considered along with healthcare, culture, art, and science in the third sector of social production, in which human capital is formed, and the intellectual values of society are created.

It is important that the development of the education system depends solely on sufficient financial support, which allows updating and multiplying the intellectual potential of the educational institution, its scientific, material, and methodological base.

Issues of studying the essence of educational institutions and the mechanism of their financing are reflected in the works of many economists, including Russian (Avetisyan, 2007; Belyakova, 2003; Gurov, Sigova, 2006; Vossenshteyn, 2003; and others), as well as Ukrainian (Volynchuk, 2009; Kalynyuk, 2011; Tymoshenko, 2008; Vaniyeva, 2006; and others).

At the same time, there was a need for a comprehensive study of the specifics of the formation of the financial mechanism ofhigher education and its main components in relation to the process of universities' transformation. Today, the regulatory and legal framework for education has been formed, the autonomy of higher education institutions has increased, new educational standards have been introduced. However, there are problems of management and financial support of higher education institutions, an optimal combination of budgetary and extra-budgetary sources of financing, and the development of an effective model for their use. In this regard, the study of issues of the formation and effective use of financial resources by higher education institutions is particularly relevant.

In Ukraine, after the adoption of the new Law "On Higher Education" in July 2014, higher education institutions received autonomy, which "is based on the idea of university autonomy, which means greater autonomy of universities in the financial, economic, and organizational spheres of activity." It is the issue of forming a strategy for the development and financing of higher education in Ukraine under conditions of European integration that is of considerable interest to all stakeholders (suppliers and consumers of educational services). In this context, it is important to study the experience of the European Union on this issue (Mospan, 2016).

An analysis of the studies conducted by the EUA Public Funding Observatory (2014), as well as the studies of Ben Jongbloed, Jamil Salmi, Stéphan VincentLancrin, and others, can help to determine the current trends in the development of higher education financing.

The purpose of the article is to study the evolution of the formation of the university development strategy and models of higher education financing on the basis of EU experience and current social and economic trends.

\section{The methodology of research}

It should be noted that researchers identify two main sources of funding for higher education - public funding and private funding as an alternative to public funding (Jongbloed, 2010; EUA Public Funding Observatory, 2014; Vincent-Lancrin, 2009). The sustainability of the functioning and development of higher education and the improvement of the quality of the training of highly qualified specialists directly depend on sufficient provision of financial resources. Therefore, the formation of a financial mechanism in the overall development strategy plays an important role in the management system of HEI.

Today, higher education in many EU countries is mainly financed from the state budget. Public funding reflects the traditional financing model, which has the goal of ensuring equal access to education. The advantages of this model are the active and diversified participation of the university in the strategic policy of the state (Salmi, 2009; Jongbloed, 2010).

In the context of current trends that directly affect the additional funding needs, namely, changing the demographic structure, the growth in demand for higher education, especially in developing countries, the transition to lifelong learning and the growth of higher education costs, researchers observe the transformation of government funding strategies for HEI for the period of 2010-2016, when for some EU countries the situation improved (EUA Public Funding Observatory, 2014; Vincent-Lancrin, 2009).

Analysis of Table 1 shows that the increase in public funding for higher education occurs in the most

Table 1

Transformation of the strategy of public financing of higher education for the period of 2010-2016

\begin{tabular}{|l|c|c|}
\hline \multicolumn{1}{|c|}{ EU countries } & Increased funding for higher education & Decreased funding for higher education \\
\hline Germany, Norway, Sweden & within $20 \%-40 \%$ & \\
\hline Austria, Belgium, France & within $10 \%-20 \%$ & up to $5 \%$ \\
\hline Poland & within 5\%-10\% & within $5 \%-10 \%$ \\
\hline Iceland, the Netherlands, Portugal & & within $10 \%-20 \%$ \\
\hline Croatia, Slovenia & & within $20 \%-40 \%$ \\
\hline Spain, Czech Republic, Serbia & & more than $40 \%$ \\
\hline Ireland, Lithuania, Italy, Great Britain & & \\
\hline Greece, Hungary & & \\
\hline
\end{tabular}


developed countries and the percentage of increased funding depends on the level of economic development of the country and vice versa, therefore Greece and Hungary show low rates.

Changes in the funding strategy for higher education have had a different impact on the activities of universities in Europe. Reducing the funding of research (research funding) was conducted in Slovenia (more than $10 \%)$, Spain, Greece, and Ireland. In particular, in Ireland, the reduction in research funding has had a negative impact on the ability of HEIs to attract and retain the best researchers and scientists.

At the same time, public authorities of Norway provided additional funding for research aimed at increasing the number of doctoral students. By teaching funding, the United Kingdom plans to reduce teaching grants from the share of overall higher education funding from $64 \%$ in 2011-2012 to the projected $17 \%$ in $2017-2018$, with transferring the cost of training to students. Note also that students in England and the EU have access to government-backed student loans, which are repaid on the income-contingent basis (Jongbloed, 2010; EUA Public Funding Observatory, 2014; Mospan, 2016).

Such loans are regularly subsidized since interest rates are associated with inflation, and the loan itself is repaid after a long period of time. It is assumed that in the future, $45 \%$ of government-backed student loans will not be reimbursed by the government (EUA Public Funding Observatory, 2014).

The EU countries use different strategies for public funding of universities and do not have a universal mechanism. J. Salmi (Salmi, 2009), who studies the development of the strategy for the development of universities and their financial mechanisms, is convinced that it is the lack of a unified model for higher education funding that causes conflicts between EU member states. B. Jongbloed (Jongbloed, 2010), points out the existence of a certain formula for funding the HEIs. $\mathrm{He}$ argues that most countries in Europe use financing formulas to determine the size of government grants for training and research. The basis for this formula is the criteria for funding HEIs, listed in Table 2.
According to the analysis of Table 2, the amount of state funding for HEIs depends on both quantitative (number of students) and qualitative (number of credits, diplomas), although qualitative indicators prevail.

This trend in the further development of the HEI strategy is confirmed by the existing mechanism for financing universities based on the results of education (performance-based funding). B. Jongbloed notes that in the Dutch funding system, the distribution of funds in HEIs by $50 \%$ depends on the number of degrees awarded, and it is the number of graduates that affects the amount of funding for universities in the future (Jongbloed, 2010). In the research budget, such elements as master's degrees and doctorate degrees partially affect the distribution of funds to HEIs.

The Norwegian funding system allocates funds according to a formula based on a combination of a fixed component $(60 \%)$ and components that depend on educational outcomes $(25 \%$ - based on student credits (ECTS) and the number of graduates) and research $(15 \%$ - based on a set of such indicators as: the number of doctoral degrees, the amount of funds received from sponsors, the number of patented studies, and the number of publications) (EUA Public Funding Observatory, 2014; Mospan, 2016).

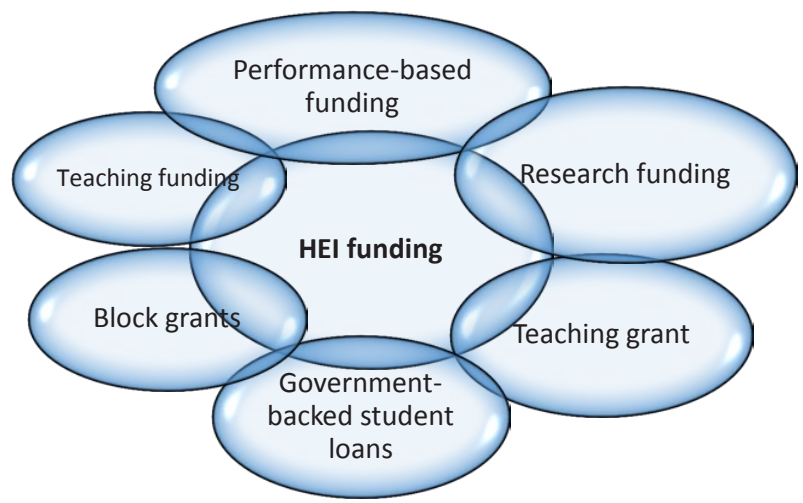

Figure 1. Mechanisms for forming higher education financing in the $\mathrm{EU}$

However, the forms of financing of HEIs in different countries vary depending on the economic, social and

Table 2

Conditions of financing of European higher education systems

\begin{tabular}{|l|l|}
\hline \multicolumn{1}{|c|}{ EU country } & \multicolumn{1}{c|}{ Grounds of public funding of the university } \\
\hline Sweden & Number of students and credits (ECTS) \\
\hline Denmark & Number of credits credited to students (ECTS) \\
\hline Belgium & Number of new students and credits to students (ECTS), number of diplomas awarded (BA, MA, PhD) \\
\hline Germany & $\begin{array}{l}\text { Budget places for last year; } \\
\text { Number of students awarded by the state }\end{array}$ \\
\hline Great Britain (England) & Number of students in the HEI \\
\hline Finland & Number of diplomas awarded (BA, MA, PhD) \\
\hline France & General criteria of the HEI (number of students and staff) \\
\hline Spain & The share of students who study on a contract basis, who received prestigious work \\
\hline The Netherlands & $\begin{array}{l}\text { Number of new students; } \\
\text { Number of diplomas awarded (BA, MA, PhD) }\end{array}$ \\
\hline
\end{tabular}


cultural conditions, political conditions, and strategic vision of the role of higher education in the state development.

In modern financing systems, mechanisms for allocating block grant funding are increasingly being developed. A block grant is understood as a grant to a local government body with the right to independently manage the grant funds. In most countries, block grant funding includes separate training and research components, calculated on the basis of various criteria (although universities have economic freedom with respect to this grant). Block grant funding for scientific research is transformed from a strategy for funding universities to performance-based funding (based on the quality of education) (EUA Public Funding Observatory, 2014).

Despite the different strategies for financing higher education that are used by EU countries, there are trends in their evolution.

Firstly, this is an increase in the direction of the distribution of costs; secondly, an increase in the correlation between the effectiveness of the HEI and the methods of financing; thirdly, active processes of a combination of different financing instruments in the context of a particular country, including the emergence of demand-based financing mechanisms.

Based on the study of the current trends in the formulation of higher education and HEI development strategies and the formation of mechanisms for their financing, three scenarios for the development of university financing can be distinguished: supplyside financing scenario, transformation scenario, and demand-side financing scenario (Figure 2) (Salmi, 2009).
The supply-side financing scenario reflects a traditional financing model that aims to support public funding for higher education and to provide equal access to it. According to this model, HEIs are mainly financed directly from the state budget (Salmi, 2009).

Such a scenario has a negative impact on the quality of education and the fairness of its distribution, especially in less developed countries. In the future, countries with predominantly public funding will be able to feel the rapid growth of secondary schools and the limitations of budgetary resources. Such states will be able to avoid the degradation of higher education only if they manage to regulate equitable access to education and evenly distribute expenditures. Otherwise, they will have unstable growth, deterioration in the quality of education, and high unemployment level among graduates over a slowdown in the creation of jobs.

The transformation scenario is observed in countries in transition in Eastern Europe and post-socialist countries (Vietnam, Russia, Poland, Armenia, Azerbaijan, Ukraine). The universities introduced a tuition fee on a selective basis, thus creating a two-channel system. The specificity of this scenario is that success at competitive entrance exams at state universities determines who should pay, and who is granted privileges. Among the possible risks of this model, the risk of inequality in access to higher education and the risk associated with less interest of contract students in the results and fewer achievements in training can be called. Reform, in this case, will be a transition to universal tuition, additional help to students, the introduction of exemption programs, scholarships and loans for students who need it and show great success (Salmi, 2009; Jongbloed, 2010; Mospan, 2016).

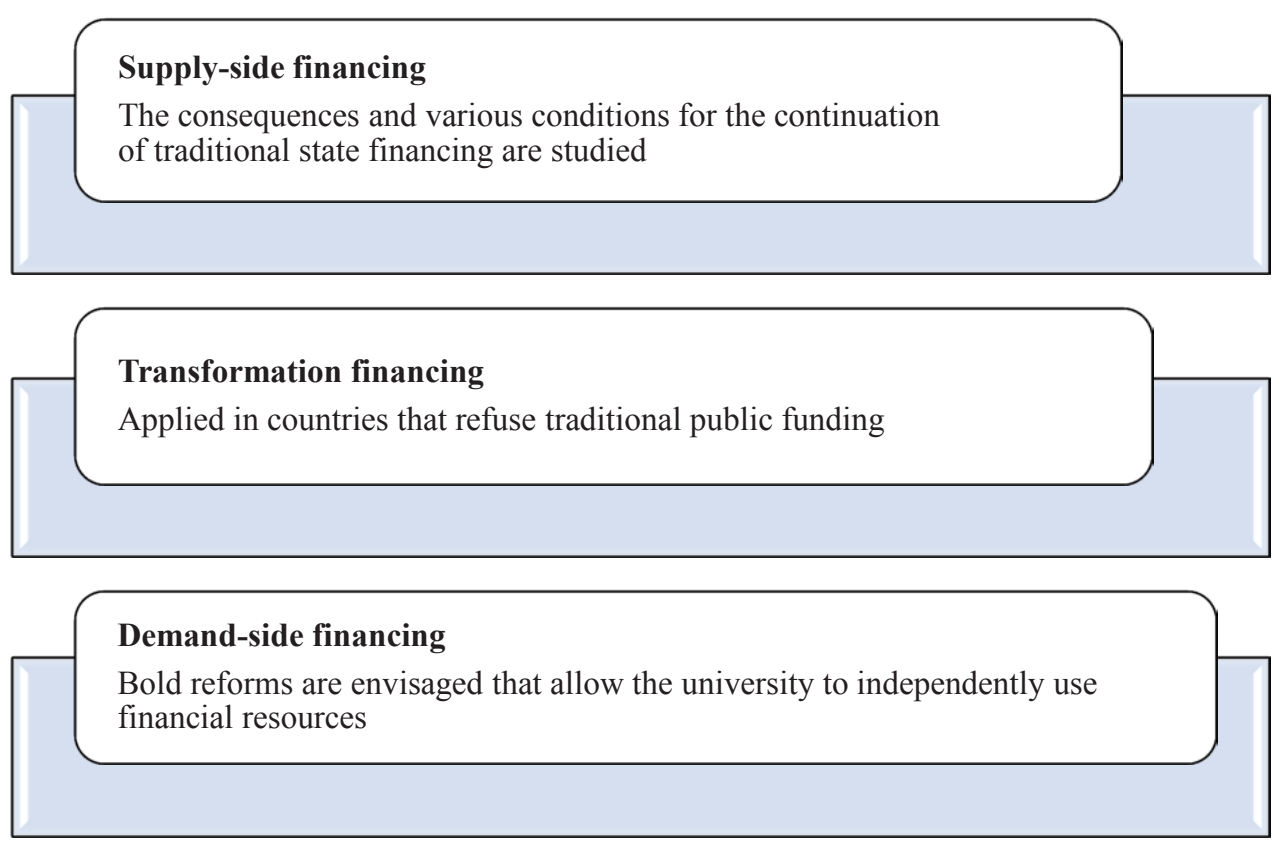

Figure 2. Scenarios for the development of the university's financial strategy 
The transformation scenario will be adopted by a growing number of countries due to the need to adjust strategies for attracting and allocating resources to the university in the face of deteriorating economic and social conditions.

A demand-based financing scenario provides for financing the higher education system mainly on the basis of market mechanisms, through which public resources are directed to support students rather than directly transferred to the HEI, as is now happening in almost all countries of the world. Also, in the long run, the schedule of state funding will change, it will not be applied only to students and graduates of educational institutions; it will also be available to older people participating in retraining or in continuing education programs throughout their working life.

So far, there have been no precedents for applying such a scenario in any country, but more developed countries are moving in this direction, increasingly using these approaches and tools.

Modern tools of demand-side financing include:

- scholarships and grants. Most countries and universities offer gratuitous financial assistance, taking into account the needs, or a scholarship for academic achievement;

- student loans. They exist in different forms in more than 60 countries. A large number of HEI organize and finance student loans;

- human capital contracts are proposed by private firms and differ from student loans. The student-participant agrees with the repayment of a part of its expenses by the investor, through the transfer of the share of the student's equity capital after graduation. Human capital contracts exist on a pilot basis in Chile, Colombia, Germany, and the USA (Mospan, 2016);

- vouchers. Six countries in the world, including Bulgaria and Hungary, have introduced the form of vouchers into the system of higher education. Students get the right to study at the university at their choice;

- education savings accounts. Education savings accounts (sometimes called "Individual Learning Accounts") are aimed at encouraging families or individuals to save on education. The state (in Belgium, the Netherlands, Spain, Sweden, Scotland, and Wales) encourages families to contribute money to their children's savings accounts, offering either tax incentives or related donations. Such accounts are used for professional training purposes; employees and employers are invited to open accounts and use the money for further training.

\section{Results and discussion}

We believe that the financial mechanism of higher education, as a part of the overall financial mechanism of the country, is an element of the implementation of the state policy in the field of higher education.
We propose a comprehensive strategy for the formation of the financial mechanism of the HEI consisting of a set of independent but interrelated forms, methods, instruments, and levers of state influence that ensure the creation and use of financial resources for the effective implementation of the educational, research, reproduction, and educational functions of the higher education system.

An important feature of such a strategy for funding a university in modern conditions is the problems of university interaction with the state. The economic relations that develop between the state and HEIs include a certain set of relationships related to property, management, the degree of universities' autonomy, financing mechanisms, etc. Therefore, for the effective functioning of such a strategy, a state program (strategy) for the development of higher education should be developed, which would provide strategic priorities in the financing of HEIs (Shevchenko, 2011).

In our opinion, the state policy in the field of higher education should include:

- the transition from the principle of maintaining higher education institutions at the expense of the state budget to state support in terms of virtually possible amounts, the development of a system of state orders for the training of personnel, but without limiting their number;

- improving and deepening the autonomy of educational institutions, especially in the field of finance;

- the transfer of a number of research institutions to the leading universities. This will improve the material and technical base of the academic, scientific, and postgraduate processes, increase the level of the teaching staff, make better use of the material, financial, and human resources of higher education;

- expansion of independence in the disposal of resources, including funds from the budget, the implementation of various activities that generate income;

- expenditure of budgetary funds should be carried out by educational institutions independently, excluding the needs of the educational process in accordance with the articles of budget classification. This can be the basis for the financial part of the university's educational strategy (Mayorova, Maydan, 2013).

The current legislation of different countries, including Ukraine, grants to the HEIs the right to use the funds allocated for the implementation of the educational process. However, modern approaches to financing significantly restrict the rights of educational institutions and, in a certain way, contradict the current legislation on education.

Elimination of such a contradiction is possible with further improvement of the financing system by:

- establishment for HEI of the amount of budgetary financing on the basis of a budget program or programtarget method;

- providing educational institutions with the opportunity to independently plan and manage 


\section{Development of a strategy for the development of higher education}

\section{Formation of the mechanism for implementing the strategy of HEI}

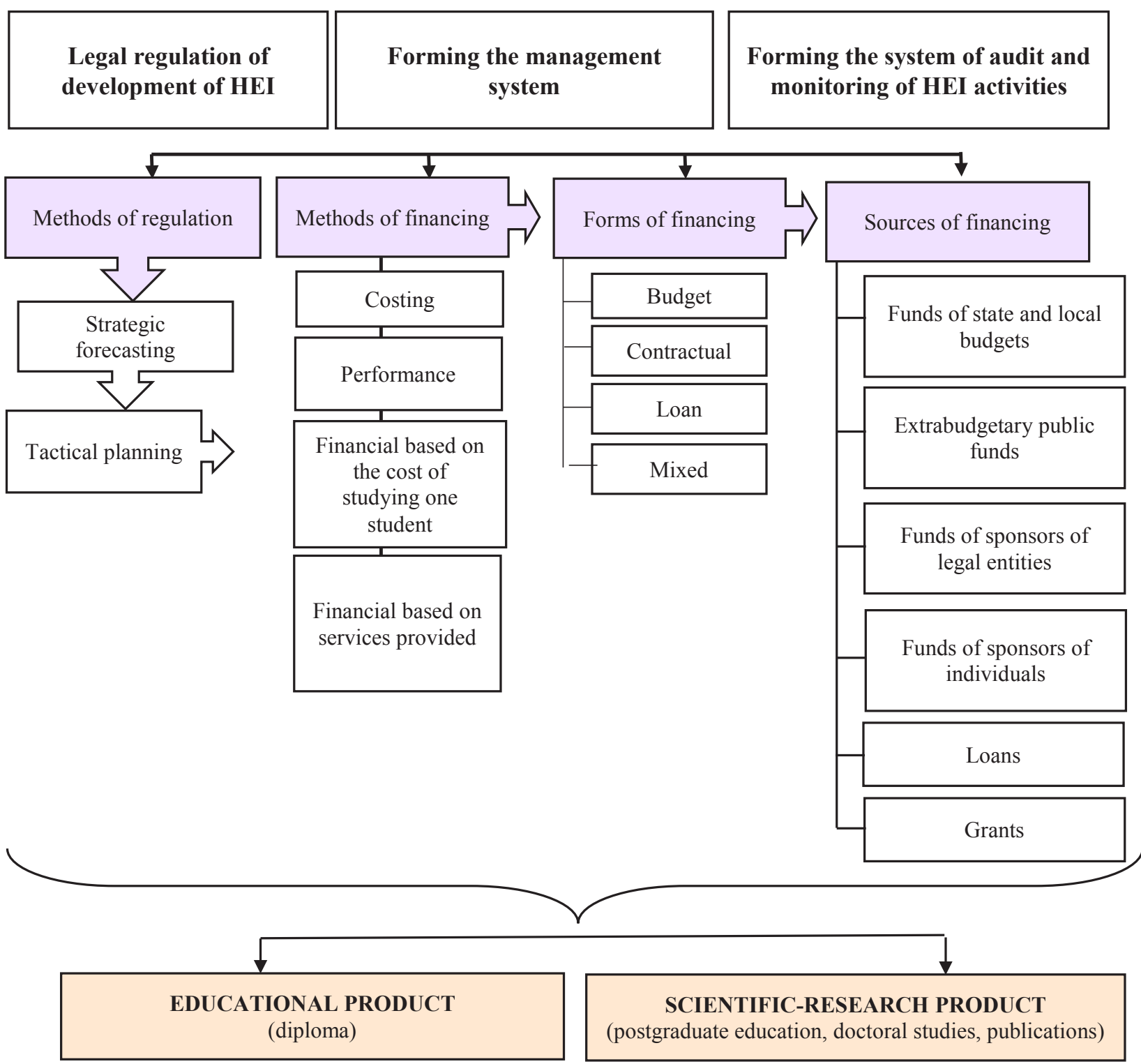

Figure 3. The scheme for forming the strategy for the development of higher education

the budget process for a medium-term (3-5 years) perspective (Rosentsvag, 2008).

Another direction for improving the strategy for the development of HEIs is to stimulate their participation in the formation of the national innovation policy through the transformation of HEIs into research centres.

In our opinion, the revenues from innovation activities of universities (the implementation of their own scientific research, including abroad) can become an important additional source of funding for higher education institutions. First of all, it concerns classical universities that have all the opportunities to interact with other sectors, combining fundamental research with sectoral research (in cooperation with departmental research institutions) and self-supporting research (on demand of business entities) (Arsenev, 2008).

We propose a methodology for calculating the rating of the scientific and educational effectiveness of the HEI, which will help both the university and its related structures to determine the effectiveness of the operation and further development prospects. 
Table 3

Methodology for calculating the rating of the scientific and educational effectiveness of the HEI

\begin{tabular}{|c|c|c|}
\hline Indicator & Calculation methodology & Weight of indicator, $\%$ \\
\hline \multicolumn{2}{|r|}{ Quality of university growth } & 33,3 \\
\hline Number of students & $\begin{array}{l}\text { Indexes of students' dynamics for the last } 5 \text { years. } \\
\text { In absolute and relative terms (including by the number of diplomas (BA, MA, } \\
\text { PhD) and credits (ECTS) }\end{array}$ & 11,1 \\
\hline Number of citations & $\begin{array}{l}\text { The share of third-party quotations in the total volume of quotations of the } \\
\text { university articles is used: } \\
\text { Number of citations without self-citations/Total number of citations } \\
\text { x } 100 \% \\
\text { If the indicator ranges from } 63 \text { to } 100 \% \text {, then the final score = } 100 \\
\text { From } 34 \text { to } 63=\text { from } 0 \text { to } 100 \\
\text { Less than } 34=0 \text { points }\end{array}$ & 11,1 \\
\hline Concentration of articles & $\begin{array}{l}\text { The calculation methodology for all subjects (except for the economics, } \\
\text { humanities, and social sciences) takes into account the number of journals in each } \\
\text { subject area: } \\
\qquad \begin{array}{l}\sum_{i}^{n}=1\left(\frac{q_{i}}{q}\right)^{\frac{1}{n}}-1 \\
n^{1-\frac{1}{n}}-1\end{array} \\
\text { where qi - the number of university articles in the journal, } \\
\mathrm{q}-\text { the number of university articles in the subject area, } \\
\mathrm{n} \text { - the number of journals, in which university articles are published. } \\
\text { For the economics, humanities, and social sciences: the index of concentration of } \\
\text { publications in journals } \sum \omega \text {, } \\
\text { where } \omega-\text { share of university articles published in the journal } \mathrm{i} \text {, in the total } \\
\text { volume of articles in this subject area) with new boundaries: } \\
\text { If the indicator is less than } 1700 \text {, then the final score }=100 \\
\text { From } 1700 \text { to } 4000=\text { from } 0 \text { to } 100 \\
\text { More than } 4000=0 \text { points }\end{array}$ & 11,1 \\
\hline \multicolumn{2}{|r|}{ The demand for scientific activity } & 33,3 \\
\hline $\begin{array}{l}\text { Field-Weighted Citation } \\
\text { Impact (FWCI) }\end{array}$ & $\begin{array}{l}\text { The number of citations of university publications relative to the average number of } \\
\text { citations received by such publications }\end{array}$ & 11,1 \\
\hline Average SNIP of journals & $\begin{array}{l}\text { The indicator is calculated as the average SNIP of journals, in which the university } \\
\text { publishes its articles. } \\
\text { SNIP - source normalized impact per paper - the average number of citations per } \\
\text { article in the journal, normalized by the differences in quoting between subject } \\
\text { areas. Consider publications for five years }\end{array}$ & 11,1 \\
\hline $\begin{array}{l}\text { Average number of citations } \\
\text { per article }\end{array}$ & $\begin{array}{l}\text { An average number of citations per article received for articles published over five } \\
\text { years }\end{array}$ & 11,1 \\
\hline \multicolumn{2}{|r|}{ The scale, stability of scientific activity } & 33,3 \\
\hline Hirsch index & $\begin{array}{l}\text { The university has an index } \mathrm{h} \text { if } \mathrm{h} \text { from its } \mathrm{Np} \text { articles is cited at least } \mathrm{h} \text { times each, } \\
\text { while the remaining }(\mathrm{Np}-\mathrm{h}) \text { articles are cited no more than } \mathrm{h} \text { times each. } \\
\text { Articles published during the last } 5 \text { years are considered }\end{array}$ & 11,1 \\
\hline Scientific Collective i-index & $\begin{array}{l}\text { The university has an index } \mathrm{h} \text { if } \mathrm{h} \text { of its } \mathrm{Np} \text { scientists has a Hirsch index of at least } \mathrm{h} \text {, } \\
\text { while the remaining }(\mathrm{Np}-\mathrm{h}) \text { scientists have a Hirsch index of not more than } \mathrm{h} \text {. } \\
\text { Scientists who have publications in the subject matter under consideration during } \\
\text { the last five years are considered. In this case, their Hirsch index is calculated for the } \\
\text { entire period }\end{array}$ & 11,1 \\
\hline Share of publications & The share of publications of the university in the subject area & 11,1 \\
\hline
\end{tabular}

When preparing the rating of scientific productivity, several categories of the most significant for the existence and development of the university are considered. When calculating the total score in the rating, an evaluation of the university's indicators is conducted in such categories (with equal shares of $33.3 \%$ ):

1. Quality of university growth.
2. The demand for scientific activity.

3. The scale, stability of scientific activity.

Categories have the same weight when calculating the final result (Mayorova, Maydan, 2013).

In such a rating, significant places are occupied by universities, which for the past four years accounted for at least $0.5 \%$ of the total number of published scientific 
articles during this period. In the calculation, articles in journals indexed by the international scientific citation database Scopus and WoS for the last 5 years should be taken into account.

\section{Conclusions}

Based on the analysis of the wholesale state support and higher education financing, models of the adaptive transition of HEIs to modern conditions of functioning were considered, using all available tools and methods.

The proposed three scenarios for funding universities show that the strategy for financing HEIs in the current dynamic development environment should shift from a traditional model of public financing (supply-side) through a transformation to financing on the basis of socio-economic mechanisms (demand-side) using different tools.

The analysis of trends in financing universities in the EU allows drawing a number of conclusions. The EU countries use different strategies for financing universities and do not have a universal mechanism. The amount of funding for HEIs depends on both quantitative (number of students) and qualitative (number of credits, diplomas) indicators. There is a tendency to allocate public funds to HEIs on the basis of learning outcomes, as well as the tendency of combining different financing instruments in the context of a particular country, including the emergence of demandside socio-economic financing mechanisms.

Socio-economic demand-side financing has several potential advantages. First, students and firms, "consumers" of educational services, are key figures. These mechanisms can stimulate universities to be more efficient economically, and students - to improve academic results and increase internal efficiency.

Secondly, the demand scenario mechanisms can be used regardless of the source of financing. They can be applied equally for the allocation of public resources and private financing of employers or students and their families.

The main disadvantage of demand-side financing mechanisms for HEIs is that they cannot be used to finance university programs that serve a public purpose. Universities compete for students and offer courses directly related to the professional interests of most students. They do not have the incentive to spend resources on general social programs with low market value or to fund research.

Financing under this scenario can only develop in countries with mixed systems of funding for HEIs (public and private HEIs), in which the transfer of public resources to private institutions is socially and politically acceptable.

In an attempt to assess the likelihood of these scenarios based on the example of a specific country, it is important to take into account not only these characteristics within national borders but also a number of international phenomena that increasingly affect national education systems. The competitiveness of international students, the presence of cross-border higher education, the emergence of the territory of the multinational educational platform and international ratings - all this plays a significant role in shaping strategic decisions regarding the future development of the HEI.

An effective process of resource management of a HEI should be based on strategic and financial benchmarks that provide for the development and implementation of a number of measures for the current activities of HEIs aimed at achieving the normal sustainability of the funding system and enhancing the university's competitive advantages. For this purpose, a methodology was proposed for calculating the scientific and educational effectiveness of the HEI.

The main directions of the strategic development of higher education in Ukraine should be the following areas.

Organizational: expansion of the autonomy of universities; government intervention in the activities of educational institutions should be limited to control over the use of budget funds allocated for the preparation of students on the state order, and compliance with state standards of higher education; diversification of educational services of HEIs in the vertical and horizontal direction; providing a full innovative-organizational cycle for applied scientific developments; activation of marketing activities of HEIs; timely update of the assets of universities (at least 1 time in 3-5 years).

Financial: distribution of budgetary funds not on the basis of standards, but on the results of activities, which stimulates the responsibility of heads of educational institutions for achieving the established standards of quality of education; economical use of financial resources; optimization of receivables and organizational structure of HEIs; application of leasing and credit instruments in financial support; change in the pricing policy for educational services; formation of stocks of financial resources; financial support for the best students of the contract form of education; application of the system of material incentives for employees for successful projects of attracting additional financial resources, etc.

State stimulation of extra-budgetary funding for education: by insuring risks associated with nonrepayment of loans provided by private companies and enterprises to citizens for education; by transferring state educational institutions to non-governmental advisory firms, companies, and attracting the private sector as an equal participant in the educational process; by creating regional co-financing programs for education by the state, the public sector, and municipal authorities; by introducing corporate communication between educational institutions and employers on the basis of bilateral agreements; by forming a system of multi-level tax payments that provide each education management 
body with certain funds necessary for the development of territorial educational complexes in accordance with the standards established by the state.

The conclusions made can serve as an example of the application of various approaches to the solution of issues of financing of the system of higher education in Ukraine. Prospects for further research in this area are seen in the study of the strategy for financing higher education in Ukraine under conditions of European integration.

\section{References:}

Avetisyan I.A. (2007). Finansirovaniye raskhodov na vyssheye obrazovaniye v rossiyskoy federatsii i napravleniya yego sovershenstvovaniya [Financing of expenses for higher education in the Russian Federation and directions for its improvement]. Problems of territory development. Vol. 39, no 4, pp. 12-27.

Belyakova S.A. (2003). Sistema finansirovaniya obrazovaniya: analiz effektivnosti [Educational Financing System: Performance Analysis]. Moscow: Techno-printing.

Modeli finansirovaniya vuzov: analiz i otsenka (2005). [Models for financing universities: analysis and evaluation]. Moscow: Techno-printing.

Gurov V.A., Sigova S.V. (2006). O finansirovanii obrazovaniya [On the financing of education]. Finansy. № 8, pp. 49-52.

Vossenshteyn Kh. (2003). Finansovoye napryazheniye: tendentsii finansirovaniya vysshego obrazovaniya i politicheskiy kurs v situatsii ogranichennykh sredstv [Financial strains: trends in financing higher education and the political course in a situation of limited means]. Universitetskoye upravleniye: praktika $\mathrm{i}$ analiz [University management: practice and analysis]. № 3(26), pp. 51-60.

Boholib T.M. (2007). Rynkova model VNZ: monohrafiya [Market model of higher education: monograph]. Kiev: Millennium.

Vaniyeva M. (2006). Ob ekonomicheskoy effektivnosti finansirovaniya obrazovaniya v Ukraine [About the economic efficiency of financing education in Ukraine]. Ekonomika: problemy teorii i praktiki: Sb. nauchn. trudov. Dnepropetrovsk.

Volynchuk Yu.V. (2009). Metodychni pidkhody do doslidzhennya ta zabezpechennya stiykosti systemy finansuvannya VNZ [Methodical approaches to research and ensuring the sustainability of the system of financing universities].

Kalynyuk I. (2011). Suchasni tendentsiyi rozvytku osvity u hlobalnomu seredovyshchi [Modern trends in the development of education in the global environment]. Universytetska osvita, № 1, pp. 20-26.

Tymoshenko O.V. (2008). Finansovi aspekty konkurentospromozhnosti vyshchoyi osvity v Ukrayini: monohrafiya [Financial Aspects of Higher Education Competitiveness in Ukraine: Monograph]. Dnipropetrovsk: Dnipropetrovskyy natsionalnyy universytet imeni Olesya Honchara.

Mayorova T.V., Maydan T.N. (2013). Puti sovershenstvovaniya finansovogo mekhanizma vysshego obrazovaniya [The ways of improving the financial mechanism of higher education]. Sovremennyye tekhnologii upravleniya. Retrieved from: https:/\%sovman.ru/article/3103/

Mospan N.V. (2016). Tendentsiyi rozvytku mekhanizmiv finansuvannya vyshchoyi osvity v Yevropeyskomu Soyuzi [Trends in the development of funding mechanisms for higher education in the European Union]. Retrieved from: https://www.narodnaosvita.kiev.ua/?page_id=2644

Jongbloed B. (2010). Funding Higher Education: A View across Europe. - The University of Twente, the Netherlands. Retrieved from: http://www.utwente.nl/bms/cheps/publications/Publications\%202010/MODERN_Funding Report.pdf

EUA Public Funding Observatory (2014). Retrieved from: http://www.eua.be/Libraries/Governance Autonomy_Funding/PFO_analysis_2014_final.sflb.ashx

Salmi J. (2009). Scenarios for Financial Sustainability of Tertiary Education. Higher Education to 2030. Volume 2: Globalisation. - OECD. Retrieved from: http://www.mfdps.si/Files/Knjiznica/higher\%20 educational\%202030\%200ECD.pdf

Vincent-Lancrin St. (2009). Finance and Provision in Higher Education: A Shift from Public to Private? Higher Education to 2030. - Volume 2: Globalisation. - OECD. Retrieved from: http://www.mfdps.si/Files/Knjiznica/ higher\%20educational\%202030\%200ECD.pdf

Arsenev D.G. (2008). International marketing of the universities educational program. (in Russian)

Rosentsvag A. (2008). About innovations in the educational system. High school in Russia, no. 8, pp. 88-92. (in Russian)

Sagonova O.V. (2011). Educational services marketing. Retrieved from: http://www.mcpg.ru/cgi-bin/rus/tour/ article.cgi? art $=1010403$ (in Russian)

Shevchenko D.A. (2011). Educational services marketing university strategy. Retrieved from: http://shevm.blogspot.ru/2011/04/blog-post_252.html (in Russian) 